\title{
Mid-Pliocene global climate simulation with MRI-CGCM2.3: set-up and initial results of PlioMIP Experiments 1 and 2
}

\author{
Y. Kamae ${ }^{1, *}$ and H. Ueda ${ }^{1}$ \\ ${ }^{1}$ Graduate School of Life and Environmental Sciences, University of Tsukuba, Tsukuba, Japan \\ *now at: Atmosphere and Ocean Research Institute, The University of Tokyo, Kashiwa, Japan
}

Correspondence to: Y. Kamae (youichi.kamae@gmail.com)

Received: 23 January 2012 - Published in Geosci. Model Dev. Discuss.: 17 February 2012

Revised: 15 April 2012 - Accepted: 26 April 2012 - Published: 25 May 2012

\begin{abstract}
The mid-Pliocene (3.3 to 3.0 million yr ago), a globally warm period before the Quaternary, is recently attracting attention as a new target for paleoclimate modelling and data-model synthesis. This paper reports setups and results of experiments proposed in Pliocene Model Intercomparison Project (PlioMIP) using a global climate model, MRI-CGCM2.3. We conducted pre-industrial and mid-Pliocene runs by using the coupled atmosphere-ocean general circulation model (AOGCM) and its atmospheric component (AGCM) for the PlioMIP Experiments 2 and 1, respectively. In addition, we conducted two types of integrations in AOGCM simulation, with and without flux adjustments on sea surface. General characteristics of differences in the simulated mid-Pliocene climate relative to the preindustrial in the three integrations are compared. In addition, patterns of predicted mid-Pliocene biomes resulting from the three climate simulations are compared in this study. Generally, difference of simulated surface climate between AGCM and AOGCM is larger than that between the two AOGCM runs, with and without flux adjustments. The simulated climate shows different pattern between AGCM and AOGCM particularly over low latitude oceans, subtropical land regions and high latitude oceans. The AOGCM simulations do not reproduce wetter environment in the subtropics relative to the present-day, which is suggested by terrestrial proxy data. The differences between the two types of AOGCM runs are small over the land, but evident over the ocean particularly in the North Atlantic and polar regions.
\end{abstract}

\section{Introduction}

The mid-Pliocene warm period (mPWP), 3.3 to 3.0 million yr ago, is a warm interval with small (or absent) Northern Hemisphere ice sheets relative to any period throughout the Quaternary (e.g. Zachos et al., 2001; Lisiecki and Raymo, 2005; Jansen et al., 2007). It is also the most recent period when global climate was substantially warmer than the present-day for a sustained time with the modern geographical distribution of continent and ocean (e.g. Haywood et al., 2009a). The effort for simulating the climate in this interval would advance validations of climate models predicting future climate change (e.g. Crowley, 1996; Salzmann et al., 2009) and to the estimation of "Earth system sensitivity" with the globally warmer climate accompanying drastic changes in land glaciers and vegetation pattern over the land (e.g. Knutti and Hegerl, 2008; Lunt et al., 2010; Pagani et al., 2010).

The paleoclimate conditions in $\mathrm{mPWP}$ are investigated by a series of studies that summarised conditions at a large number of marine and terrestrial sites and areas. As a part of the United State Geological Survey (USGS) Global Changes Research effort, the Pliocene Research Interpretation and Synoptic Mapping (PRISM) Project has documented the characteristics of climate in mPWP on a global scale by use of various types of proxy records (e.g. foraminifera, diatoms, ostracods, pollen and plant macrofossil data). The PRISM datasets (e.g. Dowsett et al., 1999) have been used to drive numerical simulations designed to explore the impact of climate forcing and feedback during the Pliocene and assess the reproducibility of climate simulations derived by general circulation models (GCMs) in this period (e.g. Haywood and Valdes, 2004; Jiang et al., 2005; Haywood et al., 2009b; 
Dowsett et al., 2011). The Paleoclimate Modelling Intercomparison Project (PMIP; e.g. Joussaume et al., 1999; Braconnot et al., 2007a, b), a worldwide framework for studying the paleoclimate reconstructions and simulations, has focused on mPWP as one of new target intervals in its latest phase (PMIP3; Otto-Bliesner et al., 2009). By applying the latest version of the PRISM dataset (PRISM3D, Dowsett et al., 2010) for prescribed boundary forcings, Pliocene modelling intercomparison project (PlioMIP) was proposed to assess the reproducibility of global climate models for mPWP climate simulations (Haywood et al., 2010, 2011). PRISM3D dataset contains all surface boundary conditions, topography, vegetation, land ice and also deep ocean temperature for initial condition in air-sea coupled climate simulations. Under the experimental protocols, several results derived by climate models had already been reported (e.g. Chan et al., 2011; Yan et al., 2011; Kamae et al., 2011; Koenig et al., 2012). In this paper, we represented the experimental setups and preliminary results of PlioMIP Experiments 1 (with atmospheric general circulation model, AGCM) and 2 (with atmosphereocean coupled general circulation model, AOGCM) for preindustrial control (Control) and mid-Pliocene (Pliocene) climate simulations with MRI-CGCM2.3 (Yukimoto et al., 2001, 2006a), which was also used in the third phase of the Coupled Model Intercomparison Project (CMIP3) and the second phase of the PMIP. In the present study, we focused on comparisons of general patterns in surface climate parameters, temperature and precipitation, for the preliminary report. The paper gives fundamental information on the modelling of Pliocene climate with MRI-CGCM2.3 and its basic results for further studies on their physical mechanisms including atmospheric and/or ocean general circulations (e.g. Hadley circulation, Walker circulation, El-Niño and Southern Oscillation, Indian Ocean Dipole mode, wind-driven surface ocean circulation, and Atlantic Meridional Overturning Circulation; AMOC) and comparisons of the simulated climate with other models and reconstructed climate revealed by proxy data. We also represent Pliocene biome prediction over the land using equilibrium biogeography model, BIOME4 (Kaplan et al., 2003), under the climate state simulated by the AGCM and AOGCMs. The biome simulations could help to compare general characteristics of surface climate patterns among the simulations by a single index translated from some elemental climate parameters (see Sect. 2.5) and facilitate quantitative model-model (e.g. Harrison et al., 1998; Wohlfahrt et al., 2008) or data-model comparisons (e.g. Haywood et al., 2009b; Pope et al., 2011; Kamae and Ueda, 2011) in the forthcoming PlioMIP papers.

\section{Climate model description}

The model used for the present study is an air-sea coupled model developed at the Meteorological Research Institute in Japan (MRI-CGCM2.3; Yukimoto et al., 2001, 2006a) for climate projections and paleoclimate simulations (e.g. Yukimoto et al., 2006b; Kitoh et al., 2007; Ohba and Ueda, 2010; Ueda et al., 2011). We employ a version with a triangular truncation at zonal wave number 42 (T42; an approximately $280 \mathrm{~km}$ transform grid) and a 30-layer hybrid sigma-pressure coordinate system with the top at $0.4 \mathrm{hPa}$. The model treats the cloud with a diagnostic scheme applying different types of relationships between cloud amount and relative humidity depends on convective/layer cloud and land/ocean regions (Yukimoto et al., 2006a). For deep moist convection, the Arakawa-Schubert scheme (Arakawa and Schubert, 1974) with prognostic closure similar to that of Randall and Pan (1993) is used in the AGCM. The land component is based on the simple biosphere $(\mathrm{SiB})$ model (Sellers et al., 1986; Sato et al., 1989), which includes the effects of vegetation. The land model has three soil layers with different field capacities depending on the vegetation type, in which the temperature, liquid water and frozen water in each soil layer are predicted. The canopy and grass are treated for each of the 13 vegetation types, for which the parameters are dependent on the vegetation type and month of the year. Runoff from the soil layers, surface runoff plus underground runoff, is transferred to either a river-mouth grid or and inland-water grid, followed by river routing.

The oceanic component is a Bryan-Cox-type global ocean general circulation model (OGCM). The horizontal resolution is $2.5^{\circ}$ longitude and $2.0^{\circ}$ latitude poleward of $12^{\circ} \mathrm{S}$ and $12^{\circ} \mathrm{N}$, with finer resolution up to $0.5^{\circ}$ near the equator for representation of equatorial oceanic waves. The vertical 23 levels are unevenly placed between the surface and the deepest bottom at $5000 \mathrm{~m}$. The sea-ice component is similar to the model developed by Mellor and Kantha (1989). Compactness and thickness are predicted based on the thermodynamics and the horizontal advection and diffusion. The freezing and melting rates of sea ice are calculated with balances of heat and fresh water at the sea-ice bottom, at the open sea surface (freezing only) and within seawater (creation of frazil ice). The advection velocities are determined from the surface ocean current multiplied by an empirical constant (set to one-third at present).

In AOGCM simulations, we performed Control and Pliocene runs using two types of model settings, with flux adjustment or without flux adjustment (see Sect. 3.1.3). In Yukimoto et al. (2006a), the climatology of present-day climate simulation was kept close to the observed conditions by using flux adjustments for heat and fresh water obtained from the last part of the $334 \mathrm{yr}$ calibration run, in which the surface temperature and salinity have been restored to the observed climatology (Levitus et al., 1994; Levitus and Boyer, 1994). Adjustment was also applied for wind stress only in the equatorial region to reproduce a realistic climatological thermocline along the equator, the structure of which plays an important role in the model performance in simulating tropical variabilities, such as El-Niño. In this study, we use the same flux adjustment values for the Control and Pliocene runs. The 
Table 1. Summary of boundary conditions and external forcings prescribed in the experiments.

\begin{tabular}{|c|c|c|c|c|}
\hline & \multicolumn{2}{|c|}{ Control } & \multicolumn{2}{|c|}{ Pliocene (alternate) } \\
\hline & AGCM & AOGCMs & AGCM & AOGCMs \\
\hline Sea surface temperature & LEVITUS94 & - & Control + PRISM3D anom & - \\
\hline Land/sea mask & \multicolumn{4}{|c|}{ MRI modern } \\
\hline Topography and ice sheet height & \multicolumn{2}{|c|}{ MRI modern } & \multicolumn{2}{|c|}{ Control + PRISM3D anom } \\
\hline Vegetation and ice sheet cover & \multicolumn{2}{|c|}{ PRISM3D modern } & \multicolumn{2}{|c|}{ PRISM3D Pliocene } \\
\hline Atmospheric $\mathrm{CO}_{2}$ concentration (ppmv) & \multicolumn{2}{|c|}{280} & \multicolumn{2}{|l|}{405} \\
\hline Other trace gases & \multicolumn{4}{|c|}{$\mathrm{CH}_{4}: 760$ ppbv, $\mathrm{N}_{2} \mathrm{O}: 270$ ppbv, CFC: none, ozone: Wang et al. (1995) } \\
\hline Solar constant $\left(\mathrm{W} \mathrm{m}^{-2}\right)$ & \multicolumn{4}{|c|}{1365} \\
\hline Orbital parameters & \multicolumn{4}{|c|}{ Eccentricity: 0.016724 , Obliquity: $23.446^{\circ}$, Precession: $102.04^{\circ}$} \\
\hline
\end{tabular}

Table 2. Integration length, initial condition and period for analysis in each run.

\begin{tabular}{|c|c|c|c|c|c|c|}
\hline & \multicolumn{2}{|c|}{ AGCM } & \multicolumn{2}{|c|}{ AOGCM_FA } & \multicolumn{2}{|r|}{ AOGCM_NFA } \\
\hline & Control & Pliocene & Control & Pliocene & Control & Pliocene \\
\hline $\begin{array}{l}\text { Ocean temperature } \\
\text { for initial condition }\end{array}$ & - & - & Present-day control & Control + PRISM3D anom & Present-day control & Control (500th yr) + PRISM3D anom \\
\hline Total integration & $60 \mathrm{yr}$ & $60 \mathrm{yr}$ & $500 \mathrm{yr}$ & $500 \mathrm{yr}$ & $1000 \mathrm{yr}$ & $500 \mathrm{yr}$ \\
\hline Averaging period & & & & Last $50 \mathrm{yr}$ & & \\
\hline
\end{tabular}

detailed model description, performance in the present-day control simulation and impact of flux adjustment to control simulation are described in Yukimoto et al. (2006a) and Kitoh et al. (2007). The geographical patterns of the flux adjustments are similar to those used in a previous version of the model (see Figs. 1-3 in Yukimoto et al., 2001).

\section{Experimental design}

\subsection{Control and Pliocene climate simulations}

\subsubsection{Dataset for boundary and initial conditions}

We apply the "PMIP3-style" boundary conditions for AGCM and AOGCMs Control simulations as detailed below. For Pliocene simulation, anomalies (mid-Pliocene minus present day) of sea surface temperature (SST; Dowsett et al., 2009), topography and ice sheet height (Sohl et al., 2009) derived from PRISM3D dataset (modern SST data is derived from Reynolds and Smith, 1995; modern topography data is derived from Edwards et al., 1992) are added to those used in the Control runs. All integrations are conducted as "alternate experiment" in which changes in land/sea mask from default setting in climate model are not required (Haywood et al., 2010, 2011). The details of experimental designs are described in Sects. 3.1.2 and 3.1.3, and summarised in Tables 1 and 2.
For surface boundary conditions in Control simulations, we use present-day realistic distribution of topography and land-sea mask (Fig. 1a) which were also used in the previous studies of climate projections for the past, present and future (e.g. Yukimoto et al., 2006a, b; Kitoh et al., 2007). In order to allow different horizontal resolutions between the atmospheric and the ocean model, the fractional coverage of landsea is considered in each AGCM grid cell (Fig. 1a). Because of the relatively coarse resolution of AGCM $(\sim 280 \mathrm{~km})$, the orography in the model is smoothed from that in reality (e.g. the highest altitude in the Himalayas is $5536 \mathrm{~m}$ ). The land cover (vegetation distribution) in the Control run is derived from PRISM3D data for modern biomes. For Control simulation with AGCM, SST is specified to modern climatology, LEVITUS94 (Levitus and Boyer, 1994). In AOGCMs, bathymetry is basically derived from ETOPO5 (NOAA, 1998), but the Denmark Strait is made slightly deeper and broader to represent the subgrid-scale overflow of waters that form in the Nordic Seas. This modification contributes to the realistic present-day thermohaline circulation in the North Atlantic (Yukimoto et al., 2006a).

The boundary conditions used in this study to reproduce Pliocene climate are derived from PRISM3D dataset (Dowsett et al., 2010). The dataset contains: SST (Fig. 8a) and deep ocean temperature (DOT; Dowsett et al., 2009), vegetation (Fig. 2, Salzmann et al., 2008), ice sheet (Figs. 1b and 2, Hill et al., 2007) and topography (Fig. 1b, Sohl et al., 2009). Reconstructed SST based on 86 sites of proxy data in 
(a) Land-ocean mask

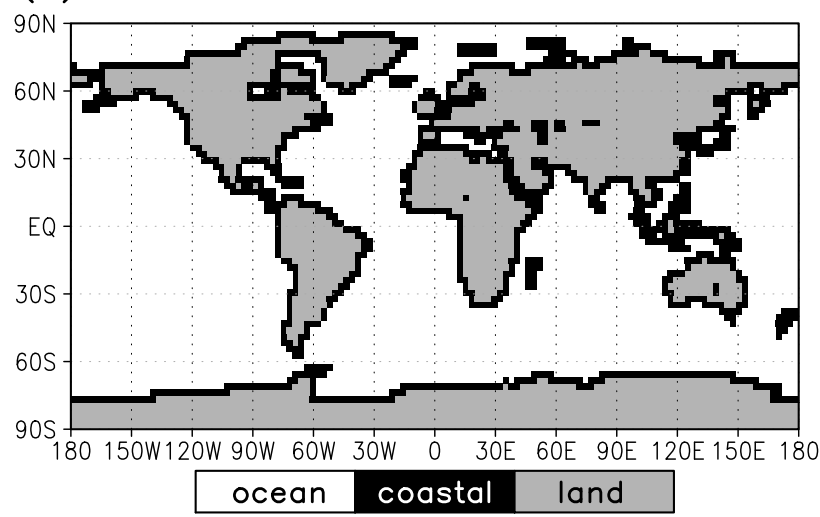

(b) Orography Plio-Cont

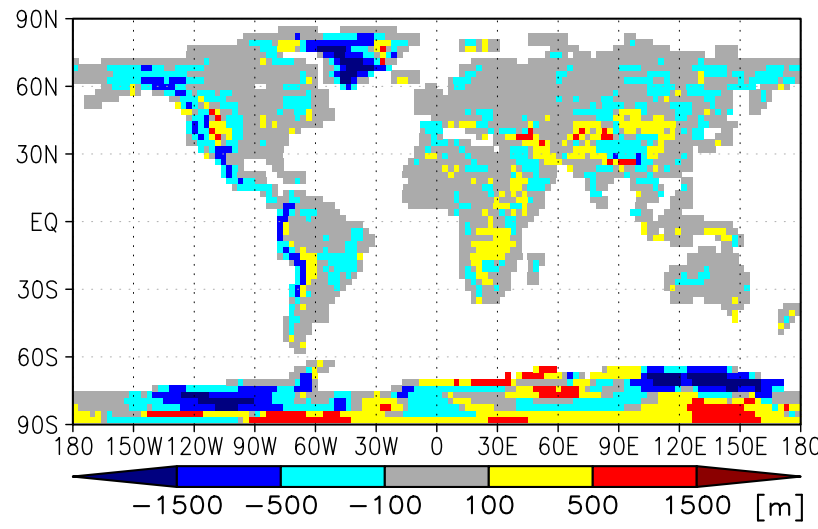

Fig. 1. Boundary conditions used in AGCM and AOGCM. (a) Landocean mask, (b) difference of orography $(\mathrm{m})$ between Pliocene and Control.

mPWP (Fig. 8a) shows vastly warmed condition in the midand high-latitude regions (Dowsett et al., 2009), especially in the northern North Atlantic $\left(\sim 18^{\circ} \mathrm{C}\right.$, Robinson, 2009). Off the western coast of the South American continent, the sea surface condition is warmed up significantly (Fig. 8a). The vegetation pattern in mPWP reconstructed by 202 sites of paleobotanical evidences and BIOME simulation (Salzmann et al., 2008) shows the poleward shift of vegetation types in mid- and high-latitude, expansion of wetter biomes in the subtropics and expansion of extratropical grassland on the Eurasian Continent in mid-latitude (Fig. 2b). We also use PRISM3D modern vegetation data for Control simulation in AGCM and AOGCMs (Fig. 2a). The PRISM3D topography (Fig. 1b) reconstructed by palaeobotanical and palaeoelevation evidences represents that the East African Rift Valley was $500 \mathrm{~m}$ higher in mPWP relative to the present value (Thompson and Fleming, 1996; Dowsett et al., 1999; Sohl et al., 2009). In contrast, the western cordilleras of the North America and the northern South America were lower than the present day. Stable isotopic, stratigraphic sea level records and pollen data on the land reveal significant reduction of the (a) Land cover Control

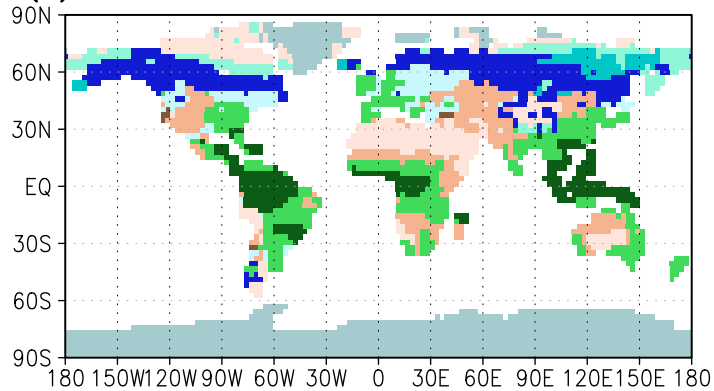

(b) Land cover Pliocene

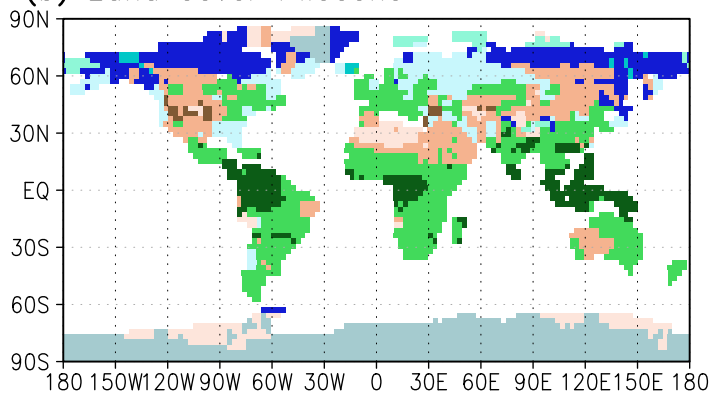

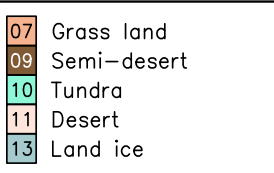

Fig. 2. Land covers prescribed in AGCM and AOGCM. (a) Control and (b) Pliocene $\mathrm{SiB}$ distribution.

continental ice sheet on Greenland and Antarctica (Thompson and Fleming, 1996; Dowsett et al., 1999). The land ice extent over Greenland was reduced by half (Dowsett et al., 1999), with the ice restricted to the high-altitude regions of East Greenland. In East Antarctica, significant ice sheet reduction was recognisable in the Wilkes and Aurora Subglacial basins (Hill et al., 2007; Haywood et al., 2010). The dataset of SST and sea ice is only applied for AGCM simulation. DOT is used for initial condition for AOGCM simulations. The concentration of atmospheric $\mathrm{CO}_{2}$ is estimated as a relatively higher level ( 350 to $415 \mathrm{ppmv}$ ) from that in the pre-industrial (e.g. Kürschner et al., 1996; Raymo et al., 1996; Pagani et al., 2010; Seki et al., 2010; Van De Wal et al., 2011).

Initial conditions of ocean for AOGCM Control integration are taken from 31 December of a present-day control simulation conducted by Yukimoto et al. (2006a) which was prescribed with a present-day boundary forcings (atmospheric $\mathrm{CO}_{2}$ concentration at $348 \mathrm{ppmv}, \mathrm{N}_{2} \mathrm{O}$ at $306 \mathrm{ppbv}$, $\mathrm{CH}_{4}$ at $1650 \mathrm{ppbv}$, solar constant at $1367 \mathrm{~W} \mathrm{~m}^{-2}$, eccentricity at 0.016715 , obliquity at $23.441^{\circ}$, and precession at $102.70^{\circ}$ ). To setup the initial conditions of ocean temperature for Pliocene simulations, we use DOT data product in PRISM3D (Dowsett et al., 2009). It was based on estimates 
in 27 locations using $\mathrm{Mg} / \mathrm{Ca}$ paleothermometry, which generally shows warmer conditions relative to today.

\subsubsection{AGCM simulation}

The experimental design for the AGCM simulation follows that which is presented in Haywood et al. (2010) as "PlioMIP Experiment 1". The integrations are conducted as "alternate experiment" of PlioMIP in which changes in land/sea mask from a default setting in climate model are not required. Figure 1a shows map of land fraction used in all the experiments (Control and Pliocene simulations with AGCM and AOGCMs) conducted in this paper. The land/sea mask being set to modern, no modifications are applied (e.g. Central American seaway, Bering Strait, Hudson Bay and West Antarctica). In a Control simulation, SST specified into the model is LEVITUS94 (Levitus and Boyer, 1994). For Pliocene simulation, anomalies of SST (Dowsett et al., 2009), topography and ice sheet height (Sohl et al., 2009) derived from PRISM3D dataset are added to those used in the Control. Sea ice cover is incorporated within the SST and is represented at grids where SST is $-1.8^{\circ} \mathrm{C}$. Types of land cover (including vegetation and land ice) are prescribed, which are PRISM3D (Salzmann et al., 2008) biome data translated into 13 types of $\mathrm{SiB}$ classification (Sellers et al., 1986; Sato et al., 1989). The translation scheme is detailed in Table 3. Figure 2 shows $\mathrm{SiB}$ distribution prescribed in the model for Control and Pliocene runs. The $\mathrm{SiB}$ distribution for the Control run was well reproduced for the presentday represented in Sato et al. (1989). The experimental settings about atmospheric composition and external forcings in this study are summarised in Table 1 . The concentration of $\mathrm{CO}_{2}$ in the atmosphere is set to 280 and 405 ppmv in Control and Pliocene. The latter is chosen to account for possible additional contributions to greenhouse warmth from non- $\mathrm{CO}_{2}$ greenhouse gases (Haywood et al., 2010, 2011). The seasonally varying ozone profile is prescribed to present-day climatological data taken from Wang et al. (1995). In Pliocene run, all other trace gases, orbital parameters and solar constant are specified as the same values as the Control settings.

Figure 3a shows time series of global-mean surface air temperature (SAT) in Control and Pliocene runs. Both simulations equilibrate in a few years and show low interannual variabilities. We integrate the AGCM for $60 \mathrm{yr}$ and calculated climatological means from the last $50 \mathrm{yr}$. Choice of the averaging period $50 \mathrm{yr}$ or $30 \mathrm{yr}$ does not show significant differences in the results.

\subsubsection{AOGCM flux- and non-flux-adjusted runs}

For the PlioMIP Experiment 2, the simulations with AOGCMs, the experimental design is based on Haywood et al. (2011). The topography, land ice, vegetation, land-sea mask, atmospheric trace-gas concentrations and the other forcings for Control and Pliocene runs are identical to the
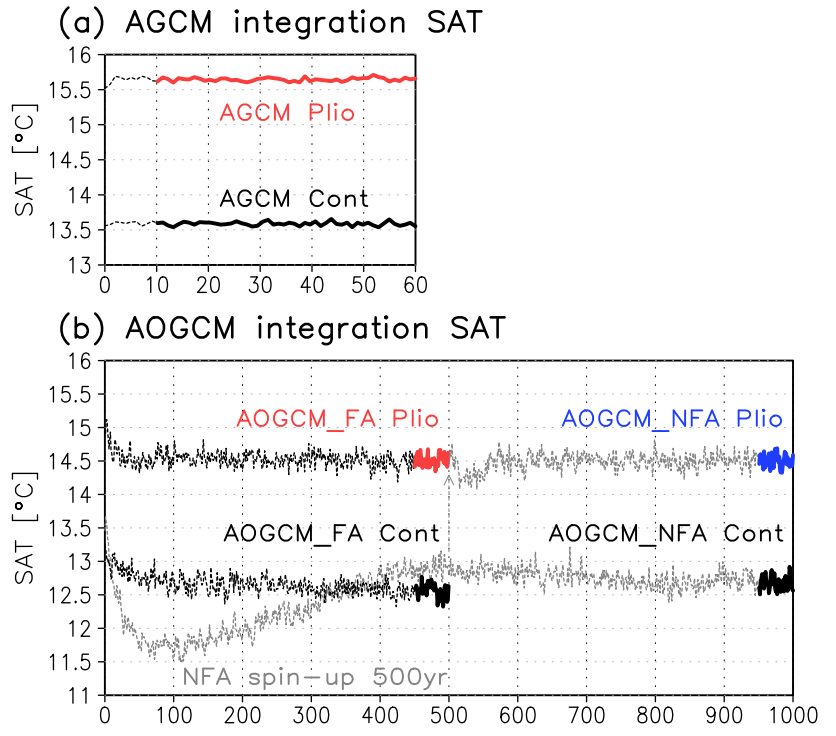

(c) AOGCM integration DOT

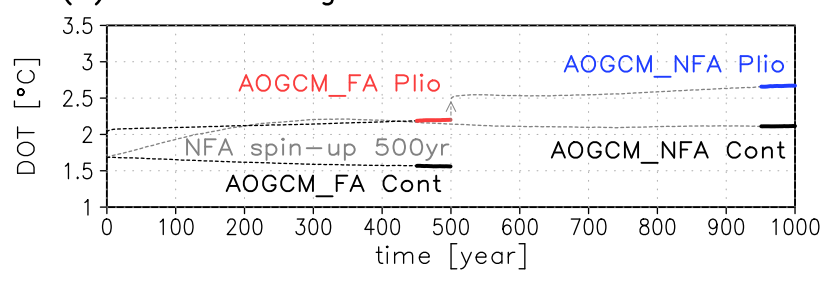

Fig. 3. Time series of the model integrations including spinups. Bold solid lines show the averaging periods of the individual simulations. (a) Globally averaged surface air temperature $\left(\mathrm{SAT},{ }^{\circ} \mathrm{C}\right)$ for the AGCM and (b) AOGCM. (c) Same as (b) but for deep ocean temperature (DOT, ${ }^{\circ} \mathrm{C}$ ) averaged for depth below $1000 \mathrm{~m}$.

AGCM simulation (Table 1). For initial condition, difference in ocean temperature at December between mPWP and modern derived from Dowsett et al. (2009) is added to the modern ocean temperature used in the Control simulation (Table 2). No modifications are applied for initial condition of the sea salinity.

We perform the PlioMIP experiments with two types of AOGCMs, with or without flux adjustment, after the second phase of the PMIP (Braconnot et al., 2007a, b). For analysis of the climate reaching near-equilibrium, we integrate the model for different terms between flux-adjusted run (AOGCM_FA) and non-flux-adjusted run (AOGCM_NFA), summarised in Table 2. We simulate the Pliocene climate by the AOGCM with and without flux adjustment and compare their sensitivities to the external forcings. In this study, we use the same flux adjustment values for the Control and Pliocene runs. In AOGCM_FA, Control and Pliocene runs with the modern and anomalous boundary conditions are integrated for $500 \mathrm{yr}$ and the last $50 \mathrm{yr}$ are used for calculation of the climatological means. In AOGCM_NFA, similar boundary and initial condition are prescribed, then 
Table 3. Converting scheme of BIOME4 vegetation types to SiB classification used in this study.

\begin{tabular}{|c|c|}
\hline BIOME4 & $\mathrm{SiB}$ \\
\hline 28. Land ice & 13. Land ice \\
\hline 27. Barren & 11. Desert \\
\hline 26. Cushion-forb, lichen, moss tundra & 10. Tundra \\
\hline $\begin{array}{l}\text { 25. Prostrate shrub tundra } \\
\text { 24. Dwarf-shrub tundra }\end{array}$ & 11. Desert \\
\hline 23. Shrub tundra & 10. Tundra \\
\hline $\begin{array}{l}\text { 22. Steppe tundra } \\
\text { 21. Desert }\end{array}$ & 11. Desert \\
\hline 20. Temperate grassland & 7. Grass land \\
\hline 19. Tropical grassland & 6. Grass land + deciduous conifer \\
\hline 18. Boreal parkland & 11. Desert \\
\hline 17. Open conifer woodland & 9. Semi-desert \\
\hline $\begin{array}{l}\text { 16. Temperate broadleaved savanna } \\
\text { 15. Temperate sclerophyll woodland }\end{array}$ & 6. Grass land + deciduous conifer \\
\hline $\begin{array}{l}\text { 14. Temperate xerophytic shrubland } \\
\text { 13. Tropical xerophytic shrubland }\end{array}$ & 7. Grass land \\
\hline 12. Tropical savanna & 6. Grass land + deciduous conifer \\
\hline 11. Deciduous taiga/montane forest & 5. Deciduous conifer \\
\hline $\begin{array}{l}\text { 10. Evergreen taiga/montane forest } \\
\text { 9. Cold mixed forest } \\
\text { 8. Cool conifer forest }\end{array}$ & 4. Evergreen conifer \\
\hline 7. Cool mixed forest & 3. Deciduous broadleaf + evergreen conifer \\
\hline 6. Warm-temperate mixed forest & 6. Grass land + deciduous conifer \\
\hline 5. Temperate conifer forest & 3. Deciduous broadleaf + evergreen conifer \\
\hline $\begin{array}{l}\text { 4. Temperate deciduous forest } \\
\text { 3. Tropical deciduous forest/woodland }\end{array}$ & 6. Grass land + deciduous conifer \\
\hline $\begin{array}{l}\text { 2. Tropical semi-deciduous forest } \\
\text { 1. Tropical evergreen forest }\end{array}$ & 1. Evergreen broadleaf \\
\hline
\end{tabular}

we integrate for $500 \mathrm{yr}$ without the flux adjustment at first. Then we continue the integration for another $500 \mathrm{yr}$ and the last $50 \mathrm{yr}$ are referred to as "AOGCM_NFA Control run". On the other hand, the anomalous ocean temperature is superimposed on the 500th yr condition in AOGCM_NFA run, then integrate for another $500 \mathrm{yr}$ prescribed with the Pliocene boundary forcings. The last $50 \mathrm{yr}$ is referred as "AOGCM_NFA Pliocene run".

Figure $3 b$ and $c$ shows time series of global mean SAT and DOT in the four integrations (Control and Pliocene runs with AOGCM_FA and AOGCM_NFA). Both of the surface conditions in Pliocene runs are warmer than those in Control runs because of the initial warming of ocean temperature imposed
Table 4. Pliocene global annual mean values and anomaly from the Control (parentheses). Energy budgets at the top of the atmosphere (TOA) are calculated as a sum of shortwave and longwave, downward minus upward.

\begin{tabular}{llll}
\hline & $\begin{array}{l}\text { TOA energy budget } \\
\left(\mathrm{W} \mathrm{m}^{-2}\right)\end{array}$ & $\begin{array}{l}\text { SAT } \\
\left({ }^{\circ} \mathrm{C}\right)\end{array}$ & $\begin{array}{l}\text { Precipitation } \\
\left(\mathrm{mm} \mathrm{day}^{-1}\right)\end{array}$ \\
\hline AGCM & $335.1(+3.8)$ & $15.6(+2.1)$ & $2.70(+0.08)$ \\
AOGCM_FA & $337.3(-0.3)$ & $14.5(+1.9)$ & $2.65(+0.10)$ \\
AOGCM_NFA & $337.8(-0.2)$ & $14.5(+1.8)$ & $2.68(+0.09)$ \\
\hline
\end{tabular}


Table 5. Trends of global annual mean values $\left({ }^{\circ} \mathrm{C} 100 \mathrm{yr}^{-1}\right)$ during the last $100 \mathrm{yr}$ in individual integrations.

\begin{tabular}{lrrrr}
\hline & $\begin{array}{r}\text { SAT } \\
(\text { Control })\end{array}$ & $\begin{array}{r}\text { SAT } \\
(\text { Pliocene })\end{array}$ & $\begin{array}{r}\text { DOT } \\
\text { (Control) }\end{array}$ & $\begin{array}{r}\text { DOT } \\
\text { (Pliocene) }\end{array}$ \\
\hline AOGCM_FA & -0.012 & 0.048 & -0.014 & 0.028 \\
AOGCM_NFA & -0.110 & 0.008 & 0.020 & 0.020 \\
\hline
\end{tabular}

on the model and the boundary forcings in the Pliocene runs. The individual runs reach their near-equilibrium which are suggested by modest trends of SST and DOT during their last $100 \mathrm{yr}$ (Table 5) and small radiative imbalance at the top of the atmosphere (TOA) during their last $50 \mathrm{yr}$ (Table 4, detailed in Sect. 4.1). Control run in AOGCM_NFA shows larger drift $\left(-0.110^{\circ} \mathrm{C} 100 \mathrm{yr}^{-1}\right)$ than the other integrations.

\subsection{Simulation of biome distribution in Pliocene}

\subsubsection{BIOME4 model}

The equilibrium biogeography model, BIOME4 (Kaplan et al., 2003), is used to translate the climate data from the AGCM and AOGCM experiments into vegetation distributions. The model predicts the most-prevailed vegetation types (biomes) as a function of the seasonal cycle of climate outputs by physiological considerations that place constraints on the growth and regeneration of different plant functional types. These constrains are calculated through the use of limiting factors for plant growth, which include mean SAT of the coldest and warmest month, annual minimum SAT, growing degree days (GDD) above 5 and $0{ }^{\circ} \mathrm{C}$, and calculation of a coefficient (Priestley-Taylor coefficient) for the extent to which soil moisture supply satisfies atmospheric moisture demand. GDDs are calculated by linear interpolated daily SAT from monthly climate data.

\subsubsection{Experimental design for Pliocene biome simulation}

In this study, we conduct one modern and three Pliocene biome simulations by using the results of climate model simulations described above. We adopt an anomaly procedure (e.g. Kaplan et al., 2003; Wohlfahrt et al., 2008; Haywood et al., 2009b; Kamae and Ueda, 2011) for three (AGCM, AOGCM_FA, and AOGCM_NFA) Pliocene biome simulations. The use of an anomaly procedure, in which the changes in climate between Pliocene and Control simulations are superimposed on an observation-based modern climatology, enables us to compensate the first-order biases in the climate control simulation (e.g. Harrison et al., 1998; Wohlfahrt et al., 2008) and extract general discrepancies in biome types caused by the uncertainties in the boundary conditions during mPWP. To apply this procedure, differences in the climatological values of monthly mean SAT, precipitation and the percent of potential sunshine hours between Pliocene and Control climate experiments are linearly interpolated to the $0.5^{\circ}$ grid of the BIOME4 model and then added to a longterm mean climatology for the 20th century, CLIMATE 2.2 (Kaplan et al., 2003). This modern climatology is an improved version of the Leemans and Cramer (1991) dataset, based on a greatly expanded weather station network. Soil properties were specified from a dataset derived from FAO global soil map (FAO, 1995). Atmospheric $\mathrm{CO}_{2}$ concentrations of 324 and 405 ppmv are used to force BIOME4 for Control and Pliocene simulations, respectively. The former is approximately the mean value during the period of measurement of the climate station data used in CLIMATE 2.2. The $\mathrm{CO}_{2}$ concentration in the latter experiment is based on the several types of proxy data during the mPWP (Dowsett et al., 2010) and is also used in Pliocene climate simulations.

\section{Results}

General characteristics of surface climate conditions during Pliocene simulated by the climate models and potential natural vegetation simulated by BIOME4 model are presented in this paper. We focused mainly on geographical patterns and difference between Pliocene and Control, and qualitative comparisons among the models (AGCM, AOGCM_FA, and AOGCM_NFA). In this section, simulated global mean values and spatial patterns of SAT and precipitation in annual, December, January and February (DJF), and June, July and August (JJA) mean field, in addition, associated changes in potential vegetation are represented.

\subsection{Global mean values}

Values of global mean SAT, precipitation rate and energy balance at TOA in Pliocene and their differences from Control simulated by the models are listed in Table 4. Except the TOA energy balance, the changes of global mean values between Pliocene and Control simulated in AGCM, AOGCM_FA and AOGCM_NFA are comparable. The surface warming in three simulations range from +1.8 to $2.1{ }^{\circ} \mathrm{C}$. The Pliocene warmings simulated with MRI-CGCM2.3 are moderate relative to those with MIROC4m under the similar experimental settings $\left(+2.8^{\circ} \mathrm{C}\right.$ in AGCM and $+3.5^{\circ} \mathrm{C}$ in AOGCM, Chan et al., 2011). The global mean SAT in Control simulations with AGCM is higher $\left(+1.1^{\circ} \mathrm{C}\right)$ than those with AOGCMs in this study. Increase in precipitation rates range from +0.08 to $0.10 \mathrm{~mm} \mathrm{day}^{-1}$. The increase of precipitation are also modest relative to MIROC4m simulations (from +0.14 to $0.21 \mathrm{~mm}$ day $^{-1}$, Chan et al., 2011).

Radiative balances at TOA in Pliocene relative to Control change for $+3.8,-0.3$, and $-0.2 \mathrm{~W} \mathrm{~m}^{-2}$ (positive downward) in AGCM, AOGCM_FA, and AOGCM_NFA, respectively. The large increase of TOA radiative balance in AGCM Pliocene simulation is consistent with the warmer surface 
condition during mPWP, including ocean. The small changes of global mean TOA energy balance in AOGCM simulations reveal that the models have reached their near-equilibrium state. Major factors for the positive changes in TOA radiative balance in AGCM run are (1) increase in atmospheric $\mathrm{CO}_{2}$ concentration (280 to $405 \mathrm{ppmv}$ ), (2) changes in cloud radiative forcing, (3) change in surface albedo corresponding with changes in cryosphere (sea ice cover, land glacier and snow cover over the land), and (4) vegetation cover.

\subsection{SAT}

Latitudinal and spatial distributions of differences in SAT between Pliocene and Control simulated by AGCM and AOGCMs are shown in Figs. 4 and 5. All runs (AGCM, AOGCM_FA and AOGCM_NFA) predict predominant warming in the higher latitude $\left(\sim+16^{\circ} \mathrm{C}\right)$ and relatively small change in low latitude $\left(\sim+2{ }^{\circ} \mathrm{C}\right.$, Fig. 4 b). SAT increases in all runs especially over the high-latitude oceans (Arctic, northern North Atlantic and Antarctic Oceans) and neighbouring land regions (Greenland and Antarctic Continent, Fig. 5a, d and g). Over the mid-latitude land regions in the Northern Hemisphere, North America and eastern Eurasian Continents, surface warmings are weak relative to their surrounding regions. It would be related to the decrease of surface albedo in those regions. Figure 6 shows changes in surface albedo between Pliocene and Control calculated by upward and downward shortwave radiation at surface. In all runs, decreases of surface albedo are dominant over the high-latitude lands (Greenland and edges of Antarctica) and the oceans (Arctic, northern North Atlantic and Antarctic Oceans, Fig. 6a to i). The former regions match with the reduction of the ice sheets (Figs. 1b, 2a and b) prescribed in the models. The surface warming in Arctic, northern North Atlantic and Antarctic Oceans (Fig. 5a, d and g) are corresponding with the reduction of sea-ice covers (Fig. 6a to i) and increasing SST (Fig. 8a, c and e). The relatively modest warming over the mid-latitude North America and eastern Eurasian Continents are corresponding with the changes in the prescribed land covers from forest to grassland (Fig. 2a and b) and associated decreases of surface albedo (Fig. 6b, $\mathrm{e}$ and $\mathrm{h}$ ). The above characteristics are common within the three runs.

Spatial characteristics of the SAT change in Pliocene from Control simulated in AGCM are different from those in AOGCMs. The surface warming in mid- and high latitude (low latitude) predicted in AGCM is generally larger (smaller) than those in AOGCMs. In AGCM run, SAT in low latitude increases only a little and decreased in the case over the land (Figs. 4d and 5a). Particularly, decrease of SAT is predominant over the subtropical North Africa, Arabian Peninsula and North India in JJA (Fig. 5c). The surface cooling over the subtropical land regions simulated in AGCM is corresponding with precipitation increase in those regions (Fig. 6c, see Sect. 4.3). For AOGCM Pliocene simulations, in
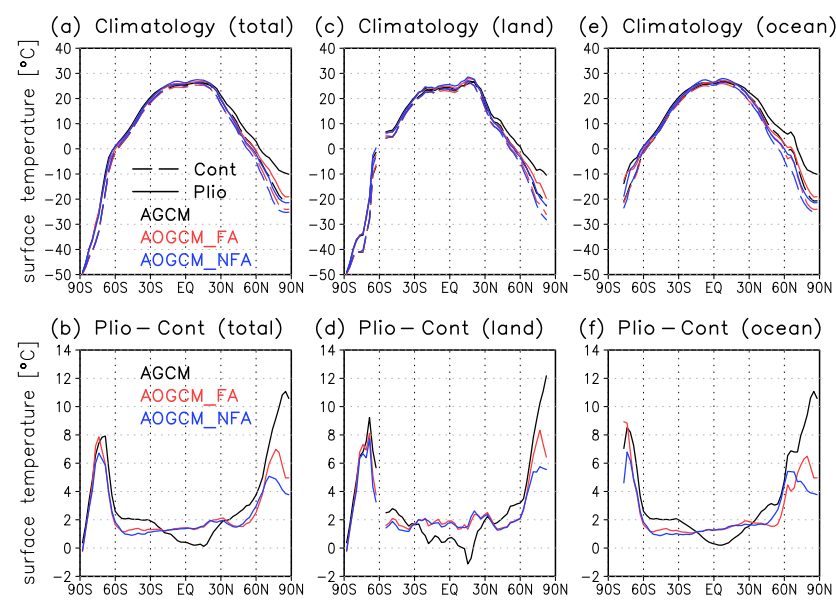

Fig. 4. (a, c, e) Zonal-mean SAT $\left({ }^{\circ} \mathrm{C}\right)$ for the Control (dashed lines) and Pliocene (solid lines) and $(\mathbf{b}, \mathbf{d}, \mathbf{f})$ their differences.

contrast, SAT increases in all latitude relative to the Control (Figs. 4b and 5). The zonal mean SATs simulated in AOGCM runs increase almost uniformly $\left(+1\right.$ to $\left.2{ }^{\circ} \mathrm{C}\right)$ in low and midlatitude (Fig. 4b). AOGCMs-predicted SATs over the land are relatively higher than those over the ocean (Figs. $4 \mathrm{c}$ and $\mathrm{f}, 5 \mathrm{~b}$ and $\mathrm{c}$ ). Note also that the reduction of the east-west temperature gradient in AGCM run (Fig. 5a) associated with the prescribed SST (Fig. 8a) is not evident in AOGCM runs (Fig. 5d and g, detailed in Sect. 5).

Different characteristics of SAT changes in Pliocene from Control are also evident between two AOGCMs, particularly in high latitude. Despite SAT simulated in AOGCM_FA, it is similar with that in AOGCM_NFA in low latitude, the former is relatively higher $\left(\sim 1\right.$ to $\left.2^{\circ} \mathrm{C}\right)$ than the latter in high latitude (Fig. 4b). In contrast, SAT over the northern North Atlantic (between $45^{\circ} \mathrm{N}$ and $70^{\circ} \mathrm{N}$ ) in AOGCM_NFA run it is higher than that in AOGCM_FA (Figs. 4f, 5b and c). The difference of SAT between AOGCM_FA and AOGCM_NFA in those regions might be closely related to the sea-ice covers (Fig. 6) and the region where deep water formation is dominant. Further detailed discussion for the difference in intensity of AMOC between the two AOGCM runs and the related possible mechanisms are necessary in future works.

\subsection{Precipitation}

Precipitation rates in all Pliocene runs increase relative to the Control runs in global mean values (Table 4), but their spatial patterns are not similar. In all runs, the precipitation changes between Pliocene and the Control in low latitude are larger than those in mid- and high-latitude (Fig. 7a to i). In AGCM run (Fig. 7a), the pattern of precipitation change in low latitude is characterised with decreasing (increasing) on the inside (outside) of the tropical rainfall zone in Control run, which was detailed in Kamae et al. (2011). For example, precipitation decreases over the tropical Indian Ocean, 


\section{SAT Pliocene minus Control}

(a) AGCM annual

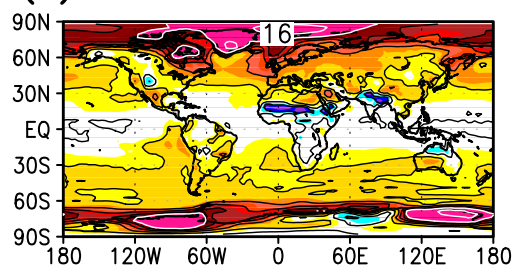

(b) AGCM DJF

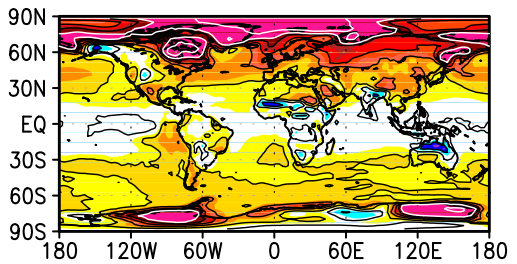

(c) AGCM JJA

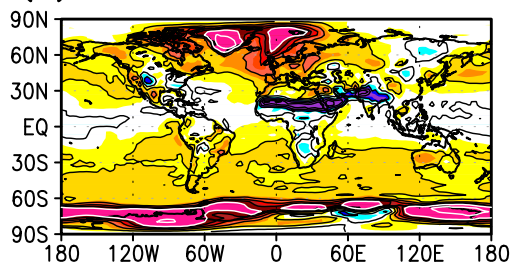

(d) AOGCM_FA annual

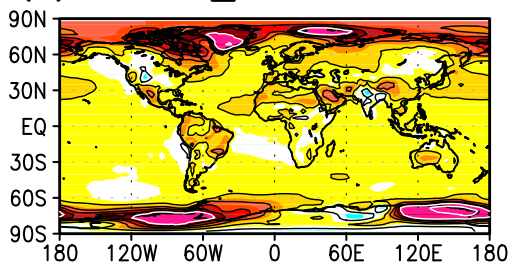

(e) AOGCM_FA DJF

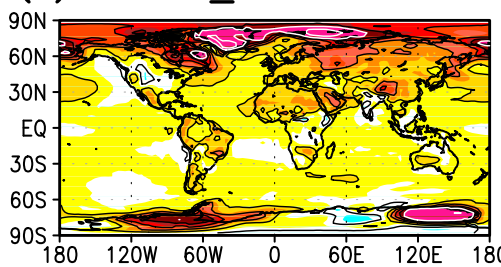

(f) AOGCM_FA JJA

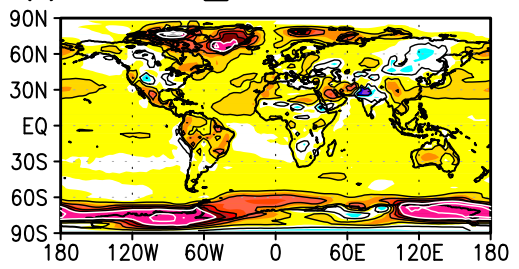

(g) AOGCM_NFA annual

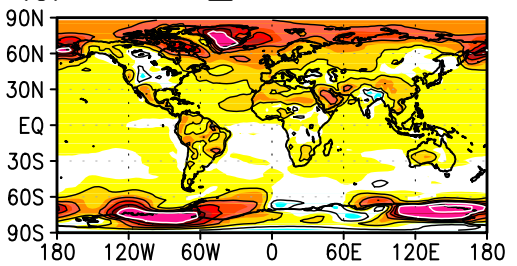

(h) AOGCM_NFA DJF

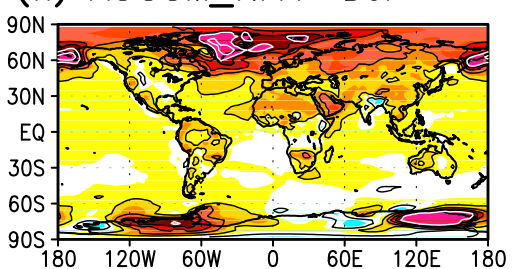

(i) AOGCM_NFA JJA

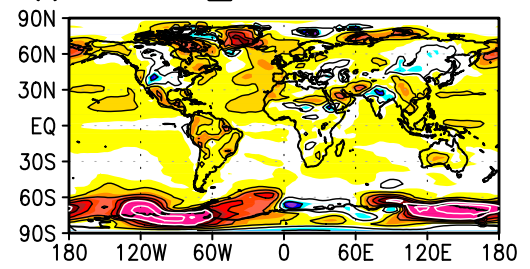

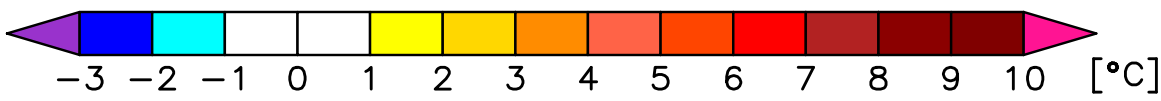

Fig. 5. Difference of SAT $\left({ }^{\circ} \mathrm{C}\right)$ between Pliocene and Control. (a, b, c) AGCM, (d, e, f) AOGCM with flux adjustment (AOGCM_FA), and (g, h, i) AOGCM without flux adjustment (AOGCM_NFA). Black and white contours represent $\pm 2,4,6,8^{\circ} \mathrm{C}$ and $\pm 10,16^{\circ} \mathrm{C}$, respectively. $(\mathbf{a}, \mathbf{d}, \mathbf{g})$ Annual, (b, e, h) December, January and February (DJF) and (c, f, i) June, July and August (JJA) mean field.

the western North Pacific, the equatorial central Pacific, the central South Pacific and the equatorial western Atlantic, and increases over the tropical and subtropical Africa, the Arabian Peninsula, the subtropical South Asia and subtropical Oceania. These patterns reveal that inter-tropical convergence zone (ITCZ) in Pliocene is broadening meridionally and zonally the rainfall accompanying large-scale convergence in ITCZ is weakening compared to the Control. On the outside (inside) of the convergence regions in the tropics, the Pliocene climate is more rainy (arid) compared to Control. The simulated wetter condition in the subtropical regions, especially in Africa and Australia, are consistent with the terrestrial proxy evidences (Salzmann et al., 2008). The systematical changes in the precipitation pattern are corresponding with changes in the atmospheric general circulations, i.e. weakening and meridional broadening of ascending motion in Hadley circulation and weakening of Walker cells over the Pacific and Indian Oceans (Kamae et al., 2011).

In AOGCM runs, changes of precipitation in low latitude, i.e. increase in the subtropics and decrease in the tropics, are modest, relative to that in AGCM (Fig. 7d and g). Except South Asia, the precipitation increases in the subtropical regions appeared in AGCM (North Africa, Arabian Peninsula and Australia) are not evident in AOGCM runs (Fig. 7d and g). The intensification of South Asian rainfall simulated by AOGCMs, particularly during JJA (Fig. 7f and i), indicates the strengthening of the Asian summer monsoon in Pliocene. The increase of precipitation in northern North Atlantic are also modest in AOGCM runs relative to AGCM run, which would be associated with relatively small SAT increase (Figs. 5 and 8). Over the tropical Atlantic Ocean, no significant changes appeared in AGCM run, but increases/decreases of precipitation in Northern/Southern Hemisphere are evident in AOGCM runs (Fig. 7d to g), particularly in AOGCM_NFA. The meridionally-asymmetric difference of precipitation over the tropical Atlantic Ocean is suggestive of meridional shift of ITCZ in Pliocene. 

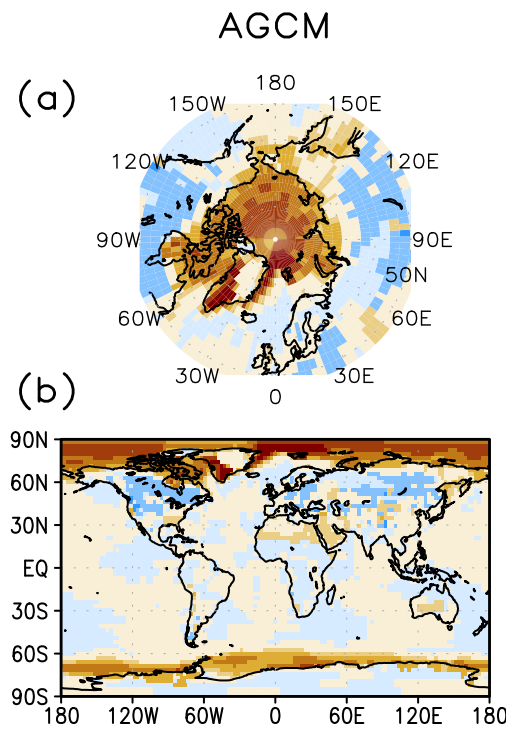

(c)

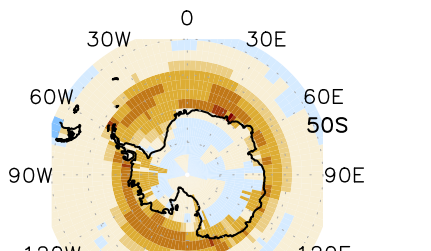

$120 \mathrm{~W}$

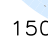

Surface albedo Plio-Cont

(d)

(e)
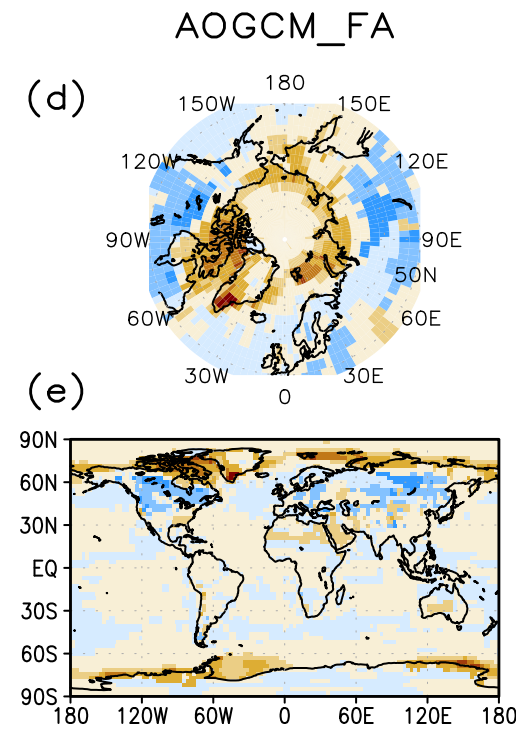

(f)

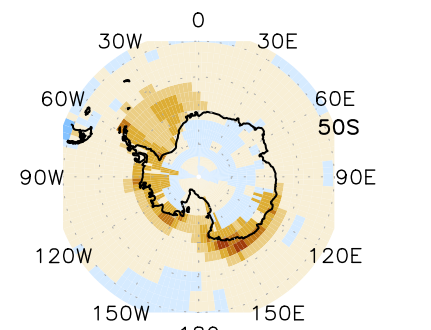

(g)

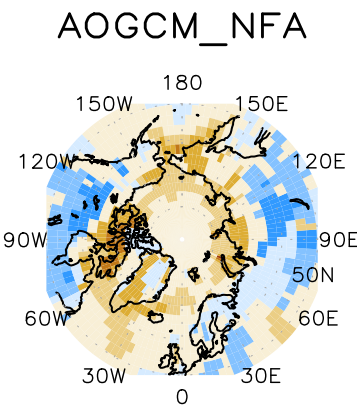

(h)

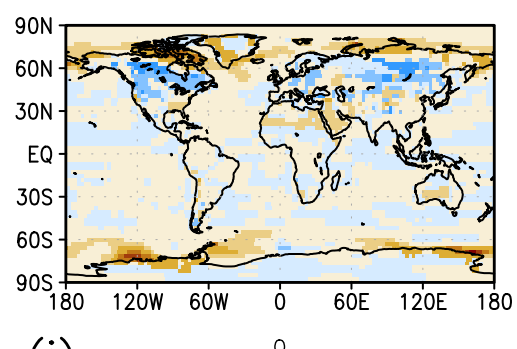

(i)

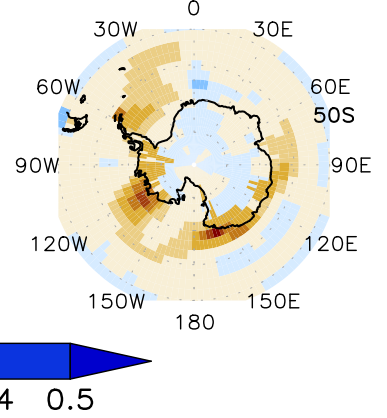

Fig. 6. Difference of surface albedo between Pliocene and Control in (a, b, c) AGCM, (d, e, f) AOGCM_FA, (g, h, i) AOGCM_NFA.

\subsection{Biome distribution}

General characteristics of the surface climate conditions predicted in AGCM and AOGCMs are compared by the single climate index, biome. Figure 9 shows present-day natural vegetation (hereafter, PD_biome) and biome distributions in Pliocene simulated with BIOME4 driven by the climate parameters predicted in AGCM, AOGCM_FA and AOGCM_NFA runs (hereafter, A_biome, AOFA_biome and AONFA_biome). In low latitude, A_biome (Fig. 9b) generally shows larger area of moister biomes than PD_biome (Fig. 9a) in accordance with the precipitation increase simulated in AGCM run (Fig. 7a). Tropical forest in equatorial and eastern South America, equatorial and South Africa, and southeastern Asia expand for wider regions in A_biome relative to PD_biome. In subtropical regions (North and South Africa, Central Asia and Australia), savanna and grassland of A_biome shift poleward, thus reducing the fractional coverage of desert. The fraction of the areas for tropical forest and desert in Pliocene relative to the present-day on African continent change for $+65 \%$ and $-30 \%$, respectively. In mid- and high-latitude, A_biome (i.e. warm-temperate forest, temperate forest, boreal forest and tundra) reveal poleward displacements relative to PD_biome. The increases in the coverages of warmer-temperate biomes in mid- and high-latitude are mainly corresponding with the warmer surface condition in AGCM run (Fig. 5a). The relative contributions of differences of the potential sunshine hours and atmospheric $\mathrm{CO}_{2}$ concentration between Pliocene and Control for the alterations in the biome patterns are minor (figures not shown) than those of the SAT and precipitation. Comparisons of the biomes with the terrestrial evidences in low and mid latitude during mPWP are detailed in Kamae and Ueda (2011).

In mid- and high-latitude, AOFA_biome and AONFA_biome also show poleward shifts of biomes relative to PD_biome. In contrast, the expansions of wetter biomes in the subtropical regions (North and South Africa, Central Asia, and Australia) are not evident in AOFA_biome and AONFA_biome. The distributions of AOFA_biome and AONFA_biome in low latitude (Fig. 9c and d) are similar to PD_biome (Fig. 9a), except the South Asia. As a general 


\section{Precipitation Pliocene minus Control}
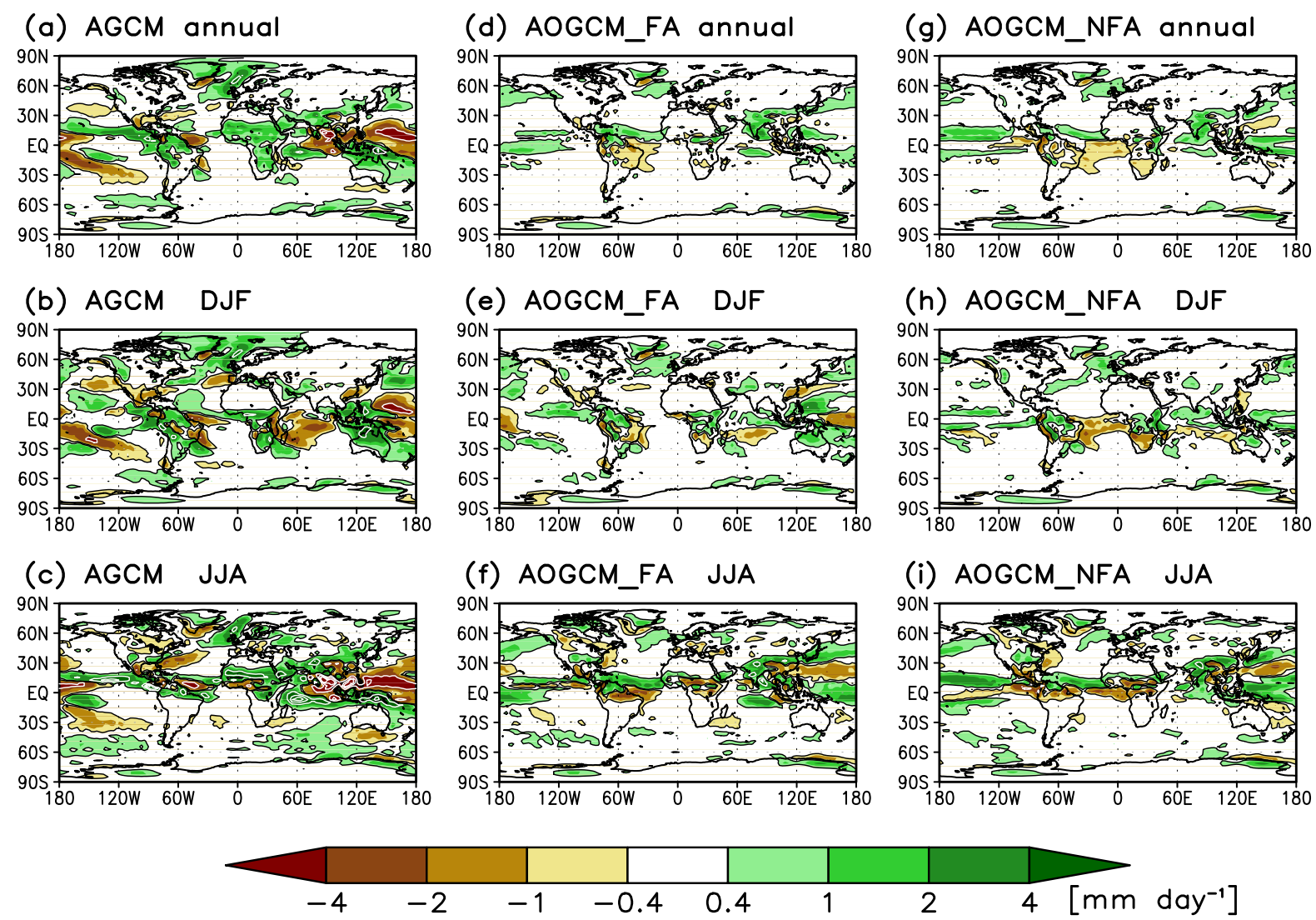

Fig. 7. Same as Fig. 5, but for precipitation rate $\left(\mathrm{mm} \mathrm{day}^{-1}\right)$. Thin black contour represents $\pm 0.8, \pm 2 \mathrm{~mm} \mathrm{day}^{-1}$ and white contour interval is $4 \mathrm{~mm}_{\text {day }}-1$.

character, the low-latitude AOFA_biome and AONFA_biome are similar to that of PD_biome, but in mid- and high latitude, they show similar pattern to A_biome. In the South Asia, the tropical forest and savanna expand for wider area in AOFA_biome and AONFA_biome than PD_biome and A_biome (Fig. 9c and d).

The reconstructed vegetations during mPWP (Salzmann et al., 2008) in tropics and subtropics are more consistent with A_biome relative to AOFA_biome and AONFA_biome. The expansion of wetter vegetation over the Africa is well simulated in A_biome (Kamae and Ueda, 2011), but those of AOFA_biome and AONFA_biome are spatially restricted. The above characteristics are corresponding with the smaller increase of precipitation over the subtropical Africa in AOGCM runs relative to AGCM run (Fig. 7a to c). The poleward shift of some temperate and cold biomes during mPWP in mid- and high latitude is qualitatively well simulated in all runs (AGCM, AOGCM_FA, and AOGCM_NFA) and is ascribed to the simulated surface warming in mid- and high latitude in all runs (Fig. 5a to c).

\section{Discussions}

The differences of the simulated climate conditions between AGCM and AOGCM runs would be closely related to SST patterns, which is prescribed as PRISM3D SST (Dowsett et al., 2009) in AGCM run but predicted in AOGCM runs. Figure 8 shows annual mean SST pattern in PRISM3D and those predicted in AOGCM runs. Comparing to Control, Pliocene SST in mid- and high latitude in PRISM3D and AOGCM runs are generally higher, particularly in the Northern Hemisphere (Fig. 8a, c and e). The prominent warming of SST in the northern North Atlantic prescribed in AGCM run (Fig. 7a) also appears in AOGCM runs (Fig. 8c and e), but the warmings are much weaker in AOGCMs $\left(\sim+4^{\circ} \mathrm{C}\right)$ than PRISM3D $\left(\sim+15^{\circ} \mathrm{C}\right)$. In low latitude, SST difference between $\mathrm{mPWP}$ and present-day in PRISM3D shows (1) generally small changes $\left( \pm 0 \sim 1^{\circ} \mathrm{C}\right.$ for average, Fig. $\left.4 \mathrm{f}\right)$ and (2) decreasing of east-west gradient because of significant warming $\left(\sim+4{ }^{\circ} \mathrm{C}\right)$ in the western coast of the continents (eastern edges of ocean basins). Above, two characteristics do not appear in the AOGCM runs. The low-latitude-mean 
(a) SST AGCM Plio - Cont (PRISM3D)

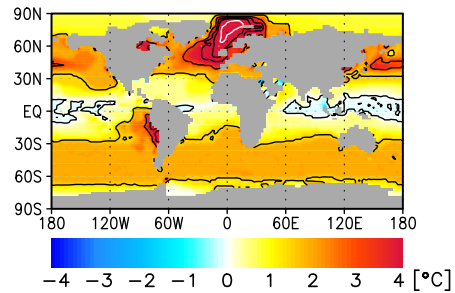

(b) SST AOGCM_FA Plio

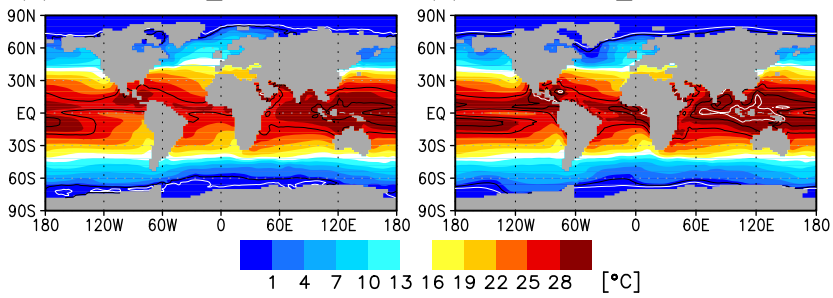

(c) SST AOGCM_FA Plio-Cont

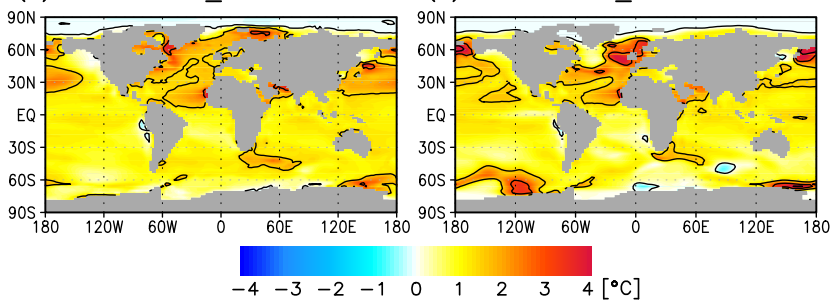

Fig. 8. (a) Difference of sea surface temperature (SST) between Pliocene and Control imposed on AGCM. (b) SST in AOGCM_FA and (d) AOGCM_NFA. (c) Difference of SST between Pliocene and Control in AOGCM_FA and (e) AOGCM_NFA. Black and white contours in (a, c, e) represent $\pm 0,1.5,3,4.5,6{ }^{\circ} \mathrm{C}$ and $\pm 10,15^{\circ} \mathrm{C}$, respectively. Black and white contours in $(\mathbf{b}, \mathbf{d})$ represent 0,27 , $29^{\circ} \mathrm{C}$ and $-1,30^{\circ} \mathrm{C}$, respectively.

changes in SST are $+1 \sim 2{ }^{\circ} \mathrm{C}$ (Fig. 4f) and the east-west SST gradient changes little $\left( \pm 0^{\circ} \mathrm{C}\right)$. These discrepancies between data and model have already been pointed out in the AOGCM Pliocene simulations in Yan et al. (2011) and Chan et al. (2011). In addition, the simulated SST changes in the northern North Atlantic show different patterns between AOGCM_FA and AOGCM_NFA runs. In AOGCM_FA run, the increasing of SST are dominated in western and northern North Atlantic, especially between $50^{\circ}$ to $60^{\circ} \mathrm{N}$ and in Barents Sea, but the SST warming in AOGCM_NFA run is evident in eastern or southern regions relative to AOGCM_FA (e.g. between $30^{\circ}$ to $40^{\circ} \mathrm{N}$ and around Iceland). Comparing to the data (Fig. 8a), both of the integrations failed to reproduce the pattern and amplitude of the SST increase in the northern North Atlantic. Dowsett et al. (2012) also shows the most models systematically underestimate the North Atlantic warming suggested by the proxy data. The discrepancy between the simulated North Atlantic SST and the proxy data indicates remaining issue in simulating the Pliocene warm climate using the modern AOGCMs under the PlioMIP protocol.
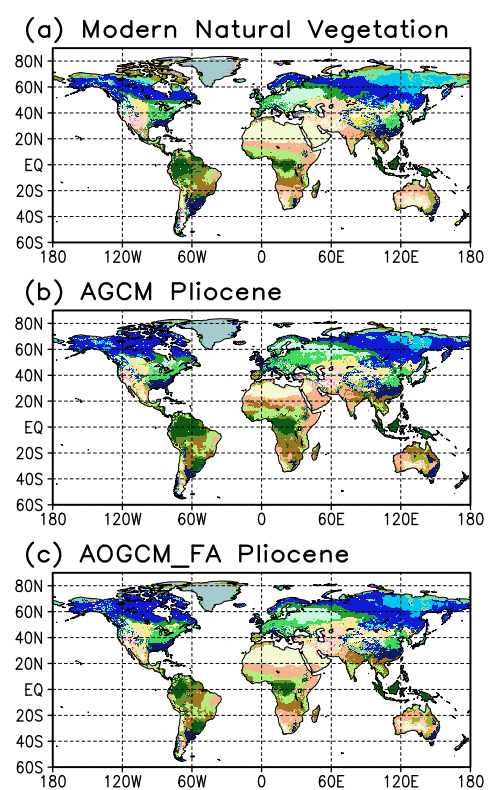

(d) AOGCM_NFA Pliocene
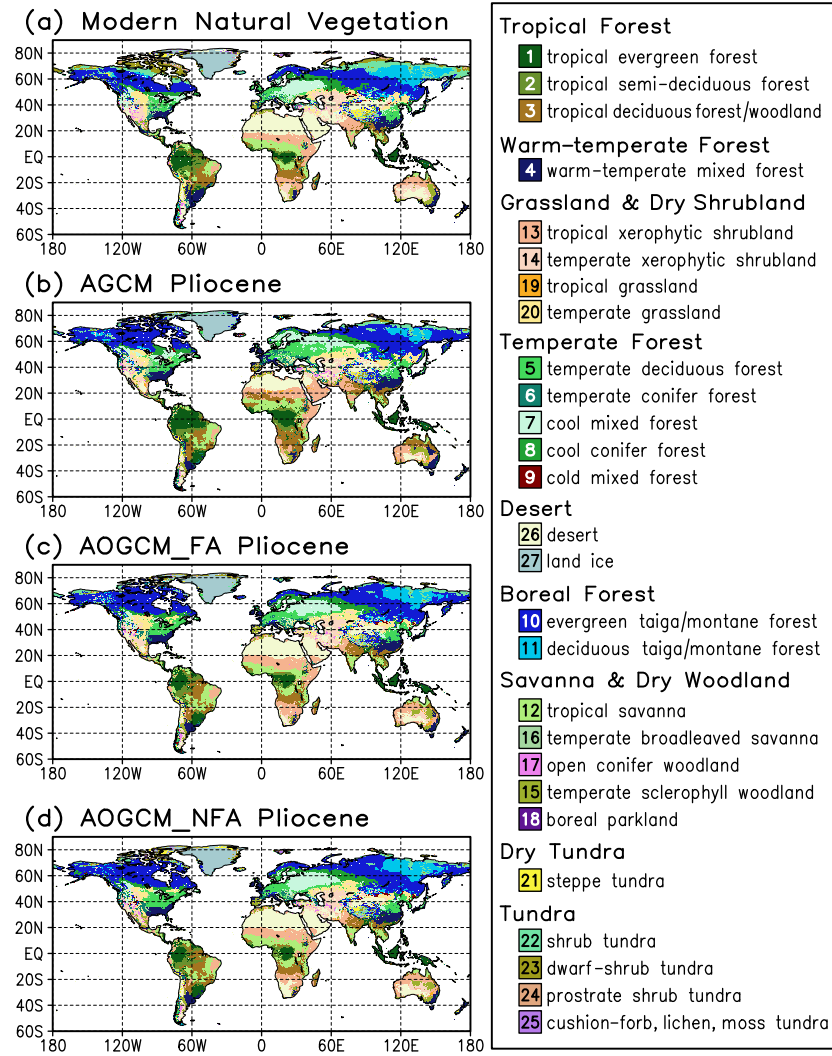

Fig. 9. (a) Present-day biomes simulated by BIOME4 model. (b) Biome distributions in Pliocene simulated with BIOME4 driven by the climate parameters predicted in AGCM (A_biome), (c) AOGCM_FA (AOFA_biome), and (d) AOGCM_NFA (AONFA_biome). Biomes were classified into 9 types of MEGABIOME category (bold) after Harrison and Prentice (2003).

The characteristics of the changes in the meridional and east-west climate patterns represented above would be associated with anomalous atmospheric and/or ocean general circulations, which are insufficiently discussed in this paper. The changes of meridional and east-west atmospheric general circulation in PlioMIP experiment 1 and its dependencies on the SST patterns have already been pointed out by Kamae et al. (2011). The simulated changes of atmospheric general circulations including Hadley and Walker circulations during Pliocene (Brierley et al., 2009; Kamae et al., 2011) are also suggested by proxy data (e.g. Etourneau et al., 2010). Changes of thermohaline and wind-driven ocean general circulations (e.g. Philander and Fedorov, 2003; Fedorov et al., 2010), including AMOC (e.g. Yan et al., 2011; Robinson et al., 2011), during Pliocene would play fundamental roles in formation and sustainment of the Pliocene climate system. The sea surface condition predicted in the AOGCMs (Fig. 8c and e) are also suggesting drastic changes in AMOC in the Pliocene simulations in this study. It is difficult to determine which run, AOGCMFA or AOGCM_NFA, is more consistent with the proxy data. However, the simulated 
AMOC and associated DOT would help to evaluate the model reproducibility. Comparing the changes in the simulated AMOC and discussing the related mechanisms under PlioMIP framework are necessary issues. Changes in surface water cycle including precipitation, evaporation, runoff, the associated sea-water salinity and sea ice cover, during the Pliocene compared to the Control, as well as AMOC reproducibility in the Control simulations might be key factors for the issues. In addition, comparison of the DOT in multi-model outputs from PlioMIP framework with the proxy data during mPWP (Dowsett et al., 2009) could help to assess reproducibility of oceanic general circulations including AMOC in Pliocene in individual models.

\section{Conclusions}

The global climate model MRI-CGCM2.3 with three types of setting, AGCM, AOGCM_FA and AOGCM_NFA, are applied to PlioMIP Experiments 1 and 2. The initial results, particularly focusing on the surface climate conditions, are reported in this paper. The calculated climatologies with the small drifts in all runs reveal that the changes in the surface climate in Pliocene from Control are quite different between AGCM run and AOGCM runs, particularly in low latitude, the North Atlantic Ocean, and the subtropical land regions. In AOGCMs, the differences are evident for the surface warming in the northern North Atlantic and the precipitation patterns in the equatorial regions, which are suggesting different characteristics in simulated meridional circulations. Further studies for the comparisons of simulated structures of atmosphere and ocean general circulations during Pliocene among multi-models and model performances evaluated by comparisons with proxy data would contribute to the investigation of the detailed aspects of the warm Earth's climate system.

\section{Appendix A}

\section{List of abbreviations}

A_biome: biome distributions in Pliocene simulated with BIOME4 driven by the climate parameters predicted in AGCM

AGCM: Atmospheric General Circulation Model

AMOC: Atlantic Meridional Overturning Circulation

AOFA_biome: biome distributions in Pliocene simulated with BIOME4 driven by the climate parameters predicted in AOGCM_FA

AOFA_biome: biome distributions in Pliocene simulated with BIOME4 driven by the climate parameters predicted in AOGCM_NFA

AOGCM: Atmosphere-Ocean coupled General Circulation Model

AOGCM_FA: Flux-Adjusted AOGCM

AOGCM_NFA: Non-Flux-Adjusted AOGCM
CMIP3: the third phase of the Coupled Model

Intercomparison Project

DJF: December, January, and February

DOT: Deep Ocean Temperature

GCM: General Circulation Model

GDD: Growing Degree Days

ITCZ: Inter-Tropical Convergence Zone

JJA: June, July and August

mPWP: mid-Pliocene Warm Period

MRI-CGCM2.3: air-sea Coupled General Circulation Model

developed at Meteorological Research Institute version 2.3

OGCM: Ocean General Circulation Model

PD_biome: Present-Day natural vegetation

PlioMIP: Pliocene Modeling Intercomparison Project

PMIP: Paleoclimate Modeling Intercomparison Project

PRISM: Pliocene Research Interpretation and Synoptic

Mapping project

SiB: Simple Biosphere model

SAT: Surface Air Temperature

SST: Sea Surface Temperature

TOA: Top Of the Atmosphere

USGS: the United State Geological Survey

Acknowledgements. The authors would like to sincerely thank the PRISM group for providing boundary dataset used in the climate modelling. We are grateful to S. Yukimoto, O. Arakawa, and A. Kitoh in the Meteorological Research Institute for providing the source code of MRI-CGCM2.3 and technical supports. Constructive comments from two anonymous reviewers have helped to improve the paper and are greatly appreciated. This work is supported by the Global Environment Research Fund (S-5-2) of the Ministry of the Environment, Japan. Part of the numerical calculation for the present work has been carried out under the "Interdisciplinary Computational Science Program" in the Center for Computational Sciences, University of Tsukuba.

Edited by: D. Lunt

\section{References}

Arakawa, A. and Schubert, W. H.: Interaction of a cumulus cloud ensemble with the large scale environment, Part I, J. Atmos. Sci., 31, 674-701, 1974.

Braconnot, P., Otto-Bliesner, B., Harrison, S., Joussaume, S., Peterchmitt, J.-Y., Abe-Ouchi, A., Crucifix, M., Driesschaert, E., Fichefet, Th., Hewitt, C. D., Kageyama, M., Kitoh, A., Laîné, A., Loutre, M.-F., Marti, O., Merkel, U., Ramstein, G., Valdes, P., Weber, S. L., Yu, Y., and Zhao, Y.: Results of PMIP2 coupled simulations of the Mid-Holocene and Last Glacial Maximum Part 1: experiments and large-scale features, Clim. Past, 3, 261277, doi:10.5194/cp-3-261-2007, 2007a.

Braconnot, P., Otto-Bliesner, B., Harrison, S., Joussaume, S., Peterchmitt, J.-Y., Abe-Ouchi, A., Crucifix, M., Driesschaert, E., Fichefet, Th., Hewitt, C. D., Kageyama, M., Kitoh, A., Loutre, M.-F., Marti, O., Merkel, U., Ramstein, G., Valdes, P., Weber, L., Yu, Y., and Zhao, Y.: Results of PMIP2 coupled simula- 
tions of the Mid-Holocene and Last Glacial Maximum - Part 2: feedbacks with emphasis on the location of the ITCZ and mid- and high latitudes heat budget, Clim. Past, 3, 279-296, doi:10.5194/cp-3-279-2007, 2007b.

Brierley, C. M., Fedorov, A. V., Liu, Z., Herbert, T. D., Lawrence, K. T., and LaRiviere, J. P.: Greatly expanded tropical warm pool and weakened Hadley circulation in the early Pliocene, Science, 323, 1714-1718, 2009

Chan, W.-L., Abe-Ouchi, A., and Ohgaito, R.: Simulating the midPliocene climate with the MIROC general circulation model: experimental design and initial results, Geosci. Model Dev., 4, 1035-1049, doi:10.5194/gmd-4-1035-2011, 2011.

Crowley, T. J.: Pliocene climates: The nature of the problem, Mar. Micropaleontol., 27, 3-121, 1996.

Dowsett, H. J., Barron, J. A., Poore, R. Z., Thompson, R. S., Cronin, T. M., Ishman, S. E., and Willard, D. A.: Middle Pliocene paleoenvironmental reconstruction: PRISM2, US Geol. Surv. Open File Rep., 99-535, 1999.

Dowsett, H. J., Robinson, M. M., and Foley, K. M.: Pliocene threedimensional global ocean temperature reconstruction, Clim. Past, 5, 769-783, doi:10.5194/cp-5-769-2009, 2009.

Dowsett, H. J., Robinson, M. M., Haywood, A. M., Salzmann, U., Hill, D., Sohl, L., Chandler, M., Williams, M., Foley, K., and Stoll, D. K.: The PRISM3D paleoenvironmental reconstruction, Stratigraphy, 7, 123-139, 2010.

Dowsett, H. J., Haywood, A. M., Valdes, P. J., Robinson, M. M., Lunt, D. J., Hill, D. J., Stoll, D. K., and Foley, K. M.: Sea surface temperatures of the mid-Piacenzian warm period: a comparison of PRISM3 and HadCM3, Palaeogeogr. Palaeocl., 309, 83-91, 2011.

Dowsett, H. J., Robinson, M. M., Haywood, A. M., Hill, D. J., Dolan, A. M., Stoll, D. K., Chan, W.-L., Abe-Ouchi, A., Chandler, M. A., Rosenbloom, N. A., Otto-Bliesner, B. L., Bragg, F. J., Lunt, D. J., Foley, K. M., and Riesselman, C.: Assessing confidence in Pliocene sea surface temperatures to evaluate predictive models, Nature Climate Change, 2, 365-371, doi:10.1038/nclimate1455, 2012.

Edwards, M.: Global gridded elevation and bathymetry, in: Global ecosystems database, version 1.0 (on CD-ROM), Documentation manual, Disc-A: National Geophysical Data Center, Key to geophysical records documentation no. 26 (Incorporated in: Global change database, volume 1), edited by: Kineman, J. J. and Ohrenschall, M. A., Boulder, CO, National Oceanic and Atmospheric Administration, A14-1 to A14-4, 1992.

Etourneau, J., Schneidera, R., Blanza, T., and Martinez, P.: Intensification of the Walker and Hadley atmospheric circulations during the Pliocene-Pleistocene climate transition, Earth Planet. Sc. Lett., 297, 103-110, 2010.

FAO: Digital soil map of the world and derived soil properties, Food and Agric. Org., Rome, 1995.

Fedorov, A. V., Brierley, C. M., and Emanuel, K.: Tropical cyclones and permanent El Niño in the early Pliocene epoch, Nature, 463, 1066-1070, 2010.

Harrison, S. P. and Prentice, I. C.: Climate and $\mathrm{CO}_{2}$ controls on global vegetation distribution at the last glacial maximum: analysis based on palaeovegetation data, biome modelling and palaeoclimate simulations, Glob. Change Biol., 9, 983-1004, 2003.

Harrison, S. P., Jolly, D., Laarif, F., Abe-Ouchi, A., Dong, B., Herterich, K., Hewitt, C., Joussaume, S., Kutzbach, J. E., Mitchell,
J., De Noblet, N., and Valdes, P.: Intercomparison of simulated global vegetation distributions in response to $6 \mathrm{kyr} \mathrm{BP}$ orbital forcing, J. Climate, 11, 2721-2741, 1998.

Haywood, A. M. and Valdes, P. J.: Modelling Pliocene warmth: contribution of atmosphere, oceans and cryosphere, Earth Planet. Sc. Lett., 218, 363-377, 2004.

Haywood, A. M., Dowsett, H. J., Valdes, P. J., Lunt, D. J., Francis, J. E., and Sellwood, B. W.: Introduction. Pliocene climate, processes and problems, Philos. T. Roy. Soc. A, 367, 3-17, 2009a.

Haywood, A. M., Chandler, M. A., Valdes, P. J., Salzmann, U., Lunt, D. J., and Dowsett, H. J.: Comparison of mid-Pliocene climate predictions produced by the HadAM3 and GCMAM3 General Circulation Models, Global Planet. Change, 66, 208-224, 2009b.

Haywood, A. M., Dowsett, H. J., Otto-Bliesner, B., Chandler, M. A., Dolan, A. M., Hill, D. J., Lunt, D. J., Robinson, M. M., Rosenbloom, N., Salzmann, U., and Sohl, L. E.: Pliocene Model Intercomparison Project (PlioMIP): experimental design and boundary conditions (Experiment 1), Geosci. Model Dev., 3, 227-242, doi:10.5194/gmd-3-227-2010, 2010.

Haywood, A. M., Dowsett, H. J., Robinson, M. M., Stoll, D. K., Dolan, A. M., Lunt, D. J., Otto-Bliesner, B., and Chandler, M. A.: Pliocene Model Intercomparison Project (PlioMIP): experimental design and boundary conditions (Experiment 2), Geosci Model Dev., 4, 571-577, doi:10.5194/gmd-4-571-2011, 2011.

Hill, D. J., Haywood, A. M., Hindmarsh, R. C. A., and Valdes, P. J.: Characterising ice sheets during the mid Pliocene: evidence from data and models, in: Deep Time Perspectives on Climate Change: Marrying the Signal from Computer Models and Biological Proxies, edited by: Williams, M., Haywood, A. M., Gregory, F. J., and Schmidt, D. H., Micropalaeontol. Soc., Spec. Pub. Geol. Soc., London, 517-538, 2007.

Jansen, E., Overpeck, J., Briffa, K. R., Duplessy J.-C., Joos, F., Masson-Delmotte, V., Olago, D., Otto-Bliesner, B., Peltier, W. R., Rahmstorf, S., Ramesh, R., Raynaud, D., Rind, D., Solomina, O., Villalba, R., and Zhang, D.: Palaeoclimate, in: Climate Change 2007: The Physical Science Basis, Contribution of Working Group I to the Fourth Assessment Report of the Intergovernmental Panel on Climate Change, edited by: Solomon, S., Qin, D., Manning, M., Chen, Z., Marquis, M., Averyt, K. B., Tignor, M., and Miller, H. L., Cambridge University Press, Cambridge and New York, 2007.

Jiang, D., Wang, H., Ding, Z., Lang, X., and Drange, H.: Modeling the middle Pliocene climate with a global atmospheric general circulation model, J. Geophys. Res., 110, D14107, doi:10.1029/2004JD005639, 2005.

Joussaume, S., Taylor, K. E., Braconnot, P., Mitchell, J. F. B., Kutzbach, J. E., Harrison, S. P., Prentice, I. C., Broccoli, A. J., Abe-Ouchi, A., Bartlein, P. J., Bonfils, C., Dong, B., Guiot, J., Herterich, K., Hewitt, C. D., Jolly, D., Kim, J. W., Kislov, A., Kitoh, A., Loutre, M. F., Masson, V., McAvaney, B., McFarlane, N., de Noblet, N., Peltier, W. R., Peterschmitt, J. Y., Pollard, D., Rind, D., Royer, J. F., Schlesinger, M. E., Syktus, J., Thompson, S., Valdes, P., Vettoretti, G., Webb, R. S., and Wyputta, U.: Monsoon changes for 6000 years ago: results of 18 simulations from the Paleoclimate Modeling Intercomparison Project (PMIP), Geophys. Res. Lett., 26, 859-862, 1999.

Kamae, Y. and Ueda, H.: Evaluation of simulated climate in lower latitude regions during the mid-Pliocene warm period using paleovegetation data, (Scientific Online Letters on the Atmosphere), 
7, 177-180, SOLA doi:10.2151/sola.2011-045, 2011.

Kamae, Y., Ueda, H., and Kitoh, A.: Hadley and Walker circulations in the mid-Pliocene warm period simulated by an atmospheric general circulation model, J. Meteorol. Soc. Japan, 89, 475-493, 2011.

Kaplan, J. O., Bigelow, N. H., Prentice, I. C., Harrison, S. P., Bartlein, P. J., Christensen, T. R., Cramer, W., Matveyeva, N. V., McGuire, A. D., Murray, D. F., Razzhivin, V. Y., Smith, B., Walker, D. A., Anderson, P. M., Andreev, A. A., Brubaker, L. B., Edwards, M. E., and Lozhkin, A. V.: Climate change and Arctic ecosystems: 2. Modeling, paleodata-model comparisons, and future projections, J. Geophys. Res, 108, 8171, doi:10.1029/2002JD002559, 2003.

Kitoh, A., Motoi, T., and Murakami, S.: El Niño-Southern Oscillation simulation at 6000 years before present with the MRICGCM2.3: Effect of flux adjustment, J. Climate, 20, 2484-2499, 2007.

Knutti, R. and Hegerl, G. C.: The equilibrium sensitivity of the Earth's temperature to radiation changes, Nat. Geosci., 1, 735743, 2008

Koenig, S. J., DeConto, R. M., and Pollard, D.: Pliocene Model Intercomparison Project Experiment 1: implementation strategy and mid-Pliocene global climatology using GENESIS v3.0 GCM, Geosci. Model Dev., 5, 73-85, doi:10.5194/gmd-5-732012, 2012.

Kürschner, W. M., Van der Burgh, J., Visscher, H., and Dilcher, D. L.: Oak leaves as biosensors of late Neogene and early Pleistocene paleoatmospheric $\mathrm{CO}_{2}$ concentrations, Mar. Micropaleontol., 27, 299-312, 1996.

Leemans, R. and Cramer, W. P.: The IIASA database for mean monthly values of temperature, precipitation, and cloudiness on a global terrestrial grid, International Institute for Applied System Analysis (IIASA), Laxenburg, Austria, 62 pp., 1991.

Levitus, S. and Boyer, T.: World Ocean Atlas Volume 4: Temperature, NOAA Atlas NESDIS 4, 117 pp., 1994.

Levitus, S., Burgett, R., and Boyer, T. P.: World Ocean Atlas, Volume 3: Salinity, NOAA Atlas NESDIS 3, 111 pp., 1994.

Lisiecki, L. E. and Raymo, M. R.: A Pliocene-Pleistocene stack of 57 globally distributed benthic $\delta^{18} \mathrm{O}$ records, Paleoceanography, 20, PA1003, doi:10.1029/2004PA001071, 2005.

Lunt, D. J., Haywood, A. M., Schmidt, G. A., Salzmann, U., Valdes, P. J., and Dowsett, H. J.: Earth system sensitivity inferred from Pliocene modelling and data, Nat. Geosci., 3, 60-64, 2010.

Mellor, G. L. and Kantha, L.: An ice-ocean coupled model, J. Geophys. Res., 94, 10937-10954, 1989.

NOAA, National Geophysical Data Center, Boulder, Colorado: Data Announcement 88-MGG-02, Digital relief of the Surface of the Earth, available at: http://www.ngdc.noaa.gov/mgg/global/ etopo5.html(last access: 15 January 2012), 1998.

Ohba, M. and Ueda, H.: A GCM study on effects of continental drift on tropical climate at the early and late Cretaceous, J. Meteorol. Soc. Jpn., 88, 869-881, 2010.

Otto-Bliesner, B. L., Harrison, S. P., and Abe-Ouchi, A.: Modeling and data syntheses of past climates, EOS Trans. AGU, 90, 93-93, 2009.

Pagani, M., Liu, Z., Lariviere, J., and Ravelo, A. C.: High Earthsystem climate sensitivity determined from Pliocene carbon dioxide concentrations, Nat. Geosci., 3, 27-30, 2010.
Philander, S. G. and Fedorov, A. V.: Role of tropics in changing the response to Milankovich forcing some three million years ago, Paleoceanography, 18, 1045, doi:10.1029/2002PA000837, 2003.

Pope, J. O., Collins, M., Haywood, A. M., Dowsett, H. J., Hunter, S. J., Lunt, D. J., Pickering, S. J., and Pound, M. J.: Quantifying Uncertainty in Model Predictions for the Pliocene (Plio-QUMP): Initial results, Palaeogeogr. Palaeocl., 309, 128-140, 2011.

Randall, D. and Pan, D.-M.: Implementation of the ArakawaSchubert cumulus parameterization with a prognostic closure, Meteorological Monograph/The representation of cumulus convection in numerical models, 46, 145-150, 1993.

Raymo, M. E., Grant, B., Horowitz, M., and Rau, G. H.: Mid-Pliocene warmth: Stronger greenhouse and stronger conveyor, Mar. Micropaleontol., 27, 313-326, doi:10.1016/03778398(95)00048-8, 1996.

Reynolds, R. W. and Smith, T. M.: A high resolution global sea surface temperature climatology, J. Climate, 8, 1571-1583, 1995.

Robinson, M. M.: New quantitative evidence of extreme warmth in the Pliocene arctic, Stratigraphy, 6, 1-10, 2009.

Robinson, M. M., Valdes, P. J., Haywood, A. M., Dowsett, H. J., Hill, D. J., and Jones, S. M.: Bathymetric controls on Pliocene North Atlantic and Arctic sea surface temperature and deepwater production, Palaeogeogr. Palaeocl., 309, 92-97, 2011.

Salzmann, U., Haywood, A. M., Lunt, D. J., Valdes, P. J., and Hill, D. J.: A new global biome reconstruction and data-model comparison for the Middle Pliocene, Global Ecol. Biogeogr., 17, 432-447, 2008.

Salzmann, U., Haywood, A. M., and Lunt, D. J.: The past is a guide to the future?, Comparing Middle Pliocene vegetation with predicted biome distributions for the twenty-first century, Philos. T. Roy. Soc. A, 367, 189-204, 2009.

Sato, N., Sellers, P. J., Randall, D. A., Schneider, E. K., Shukla, J., Kinter, J. L., Hou, Y.-Y., and Albertazzi, E.: Effects of implementing the simple biosphere model in a general circulation model, J. Atmos. Sci., 46, 2757-2782, 1989.

Seki, O., Foster, G. L., Schmidt, D. N., Mackensen, A., Kawamura, K., and Pancost, R. D.: Alkenone and boron-based Pliocene $\mathrm{pCO}_{2}$ records, Earth Planet. Sci. Lett., 292, 201-211, 2010.

Sellers, P. J., Mintz, Y., Sud, Y. C., and Dalcher, A.: A simple biosphere model $(\mathrm{SiB})$ for use within general circulation models, J. Atmos. Sci., 43, 505-531, 1986.

Sohl, L. E., Chandler, M. A., Schmunk, R. B., Mankoff, K., Jonas, J. A., Foley, K. M., and Dowsett, H. J.: PRISM3/GISS topographic reconstruction, US Geological Survey Data Series, 419, 6 pp., 2009.

Thompson, R. S. and Fleming, R. F.: Middle Pliocene vegetation: reconstructions, paleoclimatic inferences, and boundary conditions for climate modelling, Mar. Micropaleontol., 27, 27-49, 1996.

Ueda, H., Kuroki, H., Ohba, M., and Kamae, Y.: Seasonally asymmetric transition of the Asian monsoon in response to ice age boundary conditions, Clim. Dynam., 37, 2167-2179, 2011.

van de Wal, R. S. W., de Boer, B., Lourens, L. J., Köhler, P., and Bintanja, R.: Reconstruction of a continuous high-resolution $\mathrm{CO}_{2}$ record over the past 20 million years, Clim. Past, 7, 1459-1469, doi:10.5194/cp-7-1459-2011, 2011.

Wang, W.-C., Ling, X.-Z., Dudek, M. P., Pollard D., and Thompson, S. L.: Atmospheric ozone as a climate gas, Atmos. Res., 37, 247 $256,1995$. 
Wohlfahrt, J., Harrison, S. P., Braconnot, P., Hewitt, C. D., Kitoh, A., Mikolajewicz, U., Otto-Bliesner, B. L., and Weber, S. L.: Evaluation of coupled ocean-atmosphere simulations of the midHolocene using palaeovegetation data from the northern hemisphere extratropics, Clim. Dynam., 31, 871-890, 2008.

Yan, Q., Zhang, Z., Wang, H., Jiang, D., and Zheng, W.: Simulation of sea surface temperature changes in the Middle Pliocene warm period and comparison with reconstructions, Chinese Sci. Bull., 56, 890-899, 2011.

Yukimoto, S., Noda, A., Kitoh, A., Sugi, M., Kitamura, Y., Hosaka, M., Shibata, K., Maeda, S., and Uchiyama, T.: The new meteorological research institute coupled GCM (MRI-CGCM2) -Model climate and variability-, Pap. Meteorol. Geophys., 51, 47-88, 2001.
Yukimoto, S., Noda, A., Kitoh, A., Hosaka, M., Yoshimura, H., Uchiyama, T., Shibata, K., Arakawa, O., and Kusunoki, S.: Present-day and climate sensitivity in the meteorological research institute coupled GCM version 2.3 (MRI-CGCM2.3), J. Meteorol. Soc. Japan, 84, 333-363, 2006a.

Yukimoto, S., Noda, A., Uchiyama, T., Kusunoki, S., and Kitoh, A.: Climate changes of the twentieth through twenty-first centuries simulated by the MRI-CGCM2.3, Pap. Meteorol. Geophys., 56, 9-24, 2006b.

Zachos, J., Pagani, M., Sloan, Thomas, L. E., and Billups, K.: Trends, rhythms, and aberrations in global climate 65 Ma to present, Science, 292, 686-693, 2001. 